\title{
Canopy Achitecture, Biomass and Fruit Production of Solanum nigrum L. as Determined by Nitrogen Application
}

\author{
Edi Santosa $^{1 *}$, Marcella Putriantari ${ }^{1}$, Hajime Nakano ${ }^{2}$, Yoko Mine ${ }^{2}$, and Nobuo Sugiyama ${ }^{2}$
}

Diterima 08 Maret 2017/Disetujui 25 Oktober 2017

\begin{abstract}
Demand on fruits of Leunca (Solanum nigrum L.) is increasing in Indonesia due to a rapid expansion of ethnic restaurants, especially Sundanese restaurants. Most fruits come from semiintensive cultivation in intercropping system, leading to low productivity. In order to improve productivity, nitrogen experiment was carried out at field of Leuwikopo Farm of Bogor Agricultural University, Bogor-Indonesia, during rainy season from December 2013 to April 2014. Four levels of nitrogen, i.e., $0,60,120$, and $180 \mathrm{~kg} \mathrm{~N} \mathrm{ha}^{-1}$, were arranged in a randomized complete block design with four replicates. The results revealed that canopy architecture, dry matter and fruit production, and fruit quality were highly affected by nitrogen application. Increasing nitrogen levels increased biomass and fruit production. Plants treated with nitrogen at level of $60 \mathrm{~kg} \mathrm{ha}^{-1}$ produced ideal height for local labor and stable weekly fruit production than other levels. Hence, $\mathrm{N}$ fertilizer is essential for achieving high productivity of $S$. nigrum.
\end{abstract}

Keywords: canopy shape, fruit load, indigenous vegetable, leunca, ranti kebo

\begin{abstract}
ABSTRAK
Permintaan buah Leunca (Solanum nigrum L.) terus meningkat di Indonesia sejalan dengan perkembangan restoran etnis khususnya restoran Sunda. Sebagian besar buah leunca berasal dari tanaman sampingan secara tumpangsari, sehingga produktivitas rendah. Dalam rangka meningkatkan produktivitas, percobaan pemberian nitrogen dilakukan di Kebun Percobaan Leuwikopo IPB, Bogor pada musim hujan Desember 2013 sampai April 2014. Nitrogen diberikan empat taraf yaitu 0,60, 120, dan $180 \mathrm{~kg} \mathrm{~N} \mathrm{ha}^{-1}$, yang disusun dalam rancangan acak kelompok dengan empat ulangan. Hasil menunjukkan bahwa bentuk kanopi, produksi bahan kering dan produksi buah serta kualitas buah dipengaruhi oleh pemberian nitrogen. Peningkatan dosis nitrogen meningkatkan bahan kering dan produksi buah. Tanaman dengan perlakuan $60 \mathrm{~kg} \mathrm{~N} \mathrm{ha-1}$ menghasilkan tinggi yang ideal bagi pemanen, dan hasil mingguan yang stabil dibandingkan dengan taraf yang lebih besar. Oleh karena itu, pemupukan nitrogen penting dilakukan untuk meningkatkan produktivitas leunca.
\end{abstract}

Kata kunci: beban buah, bentuk kanopi, leunca, ranti kebo, sayuran tradisional

\section{INTRODUCTION}

Black nightshade (Solanum nigrum $\mathrm{L}$ ) in Indonesia is called leunca in Sundanese or ranti kebo in Javanese. It grows in fields and homegardens, in intercropping system (Santosa et al., 2015). Traditionally, the green mature fruits are consumed locally by Sundanese (Santosa et al., 2015) and the leaves are locally consumed as leafy vegetables by Javanese, like in African countries (Ondieki et al., 2011; Gokavi et al., 2014). With the growing of Sundanese restaurant, demand for fruit is increasing (Santosa et al., 2015). There have been many studies on medicinal and functional properties of fruits and leaves of $S$. nigrum and its relatives including glycoalcaloids, glycoproteins, polyphenol compounds and polysaccharides (Ravi et al., 2009; Karmakar

\footnotetext{
${ }^{1}$ Faculty of Agriculture, Bogor Agricultural University, J1. Meranti Kampus IPB Darmaga, Bogor 16680, Indonesia ${ }^{2}$ Faculty of Agriculture, Tokyo University of Agriculture, Funako, Atsugi, Kanagawa 243-0034, Japan Emai: edisang@gmail.com (*Corresponding author)
} 
et al., 2010; Mohy-ud-din et al., 2010; Jain et al., 2011; Sudhanshu, 2012; Gogoi and Islam, 2012). However, there was few studies on the management for high fruits yield in S. nigrum in Indonesia.

$S$. nigrum belongs to the group of Solanum nigrum complex that spreads throughout tropical and temperate regions up to an elevation of $3048 \mathrm{~m}$ (Edmonds and Chweya, 1997). Edmonds and Chweya (1997) describes $S$. nigrum is an annual plant growing to a height of $70 \mathrm{~cm}$; flowers are medium, corolla stellate and white in a sub-umbellate inflorescence; 5-20 flowered cymes, fruiting pedicels reflexed or erecto-patent; fruit is a ovoid-globose 6-10 $\mathrm{mm}$ in diameter, and purplish-black dull at maturity.

Here, canopy architecture, biomass and fruit production of $S$. nigrum from different nitogren level are evaluated. $\mathrm{N}$ level has been known to determine plant architecture of Solanaceae family members (Etissa et al., 2013; Bvenura and Afolayan, 2014; Gokavi et al., 2014; Putriantari and Santosa, 2014). Plant architecture is important because it determines crop production (Ravi et al., 2013) and management (Sarlikioti et al., 2011; Degri, 2014) especially on weed control and easiness to harvest. Hence, the objective of this research was to determine the effect of nitrogen application on plant architecture, biomass and fruit production of S. nigrum in order to improve production in intercropping system.

\section{MATERIAL AND METHODS}

A field experiment was conducted at Leuwikopo Farm, Bogor Agricultural University, Bogor, Indonesia, during rainy season from December 2013 to April 2014 (21-30 rainy days per month) using soil of latosol Darmaga type. Daily rainfall ranged from $0.2-103.3 \mathrm{~mm}$, temperature $24.6-33.5$ ${ }^{0} \mathrm{C}$, and relative air humidity $79-89 \%$. Dolomite $\left(\mathrm{CaCO}_{3}\right)$ at a rate of $1 \mathrm{t} \mathrm{ha}^{-1}$ was incorporated during land preparation ( 2 weeks before planting). Soil after dolomite application had $\mathrm{pH}\left(\mathrm{H}_{2} \mathrm{O}\right) 4.5$ with $0.95 \%$ organic carbon (Walkley and Black), $0.10 \%$ total N (Kjeldahl), 5.6 ppm P (Bray I), 15.2 and $3.2 \mathrm{me} \mathrm{kg}^{-1}$ exchangeable $\mathrm{Ca}$ and $\mathrm{K}$, and $26.1 \%$ base saturation, $1.93 \mathrm{ppm} \mathrm{Fe}, 2.88 \mathrm{ppm}$
$\mathrm{Cu}, 4.67 \mathrm{ppm} \mathrm{Zn}$, and $56.63 \mathrm{ppm} \mathrm{Mn.} \mathrm{Goat}$

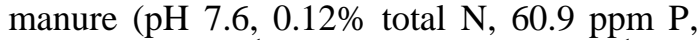
and $23.8 \mathrm{me} \mathrm{kg}^{-1} \mathrm{~K}$ ) at a rate of $10 \mathrm{t} \mathrm{ha}^{-1}$ was applied approximately $0.6 \mathrm{~kg}$ per plant at one week before planting.

Seeds of $S$. nigrum were collected in November 2013 and sowed immediately in a green house. On December 17, 2013 (5 weeks after sowing), they were transplanted into field. Non-surviving plants were replaced by supplementary seedlings within a week after planting.

Four levels of nitrogen (N) were applied, i.e., 0, 60, 120 and $180 \mathrm{~kg} \mathrm{~N} \mathrm{ha}{ }^{-1}$. Plots were arranged by a randomized complete block design with four replications. Cultivation and sampling methods followed Putriantari and Santosa (2014). Briefly, plants were arranged at double rows at a distance of $50 \mathrm{~cm} \times 70 \mathrm{~cm}$ on planting bed that suit 20 plants. Seedling height was $15 \pm 2 \mathrm{~cm}$. One third and two third of the total amount of $\mathrm{N}$ were applied by side-dressing one and six weeks after transplanting (WAP), respectively. Together with first $\mathrm{N}$ application, phosphorus $\left(\mathrm{P}_{2} \mathrm{O}_{5}\right)$ and potassium $\left(\mathrm{K}_{2} \mathrm{O}\right)$ fertilizers were applied at a rate of $120 \mathrm{~kg} \mathrm{ha}^{-1}$ each. Ten plants were randomly selected for measurement in each experimental unit. Plants were protected using insecticides profenofos $\left(\right.$ Curacron $\left.{ }^{\circledR}\right)$ and propineb (Antracol $\left.{ }^{\circledR}\right)$. Irrigation water was applied if rainfall for three consecutive days less than $2 \mathrm{~mm}$.

Plant height was grouped into short (< $100 \mathrm{~cm})$, medium $(100-135 \mathrm{~cm})$ and high $(>135 \mathrm{~cm})$ for easiness of harvest based on average height of woman worker. Canopy shape was evaluated by dividing canopy width to it height, i.e., columnar (ratio < 0.5 ), ovalglobe $(0.5-1.0)$, broadly-round (1.1-1.5), and spreading ( $>1.5$ ), number of flower reaching anthesis, number of inflorescences and inflorescences with fruits proper stage of harvest were measured weekly. Destructive sampling of extra three plants was carried out at 6 WAP (before second $\mathrm{N}$ application) and 12 WAP. Plant parts were separated and ovendried to constant mass at $80{ }^{\circ} \mathrm{C}$ for 3 days. Fruits were classified into small $(<3 \mathrm{~mm})$, medium $(3-7 \mathrm{~mm})$ and large $(>7 \mathrm{~mm})$. Data were analyzed by ANOVA. Duncan's Multiple Range Test (DMRT) was conducted to detect significant differences between treatments. 


\section{RESULTS AND DISCUSSIONS}

\section{Plant Architechture}

Nitrogen application significantly increased plant height (Figure 1). Plant height of $100-135 \mathrm{~cm}$ was desirable because it was easy to harvest. Thus, $\mathrm{N}$ application at rate 60 and $120 \mathrm{~kg} \mathrm{ha}^{-1}$ produced the ideal plant height in present experiment. Application of $\mathrm{N}$ larger than $120 \mathrm{~kg} \mathrm{ha}^{-1}$, increased number of plant with ideal height by about $11 \%$ than control. Ondieki et al. (2011) has stated that plant height of S. americanum increases by $48 \%$ with compost application at level of 8 ton ha ${ }^{-1}$; and Gokavi et al. (2014) stated that NPK at a rate of $125: 75: 75 \mathrm{~kg} \mathrm{ha}^{-1}$ to $S$. nigrum increased plant height as compared to without fertilizer.

Plants received $180 \quad \mathrm{~kg} \quad \mathrm{~N} \quad \mathrm{ha}^{-1}$ significantly produced wider canopy and higher leaf area index (LAI) (Table 1). However, many branches bent downward due to high fruit load of plants received high $\mathrm{N}$ level, resulted in variation on plant heigt as shown in Figure 1.

Level of $\mathrm{N}$ determined canopy shape (Table 1). In absence of supplement $\mathrm{N}$ fertilizer, canopy shaped globe. The canopy expanded into broadly-round at $60 \mathrm{~kg} \mathrm{~N} \mathrm{ha}^{-1}$, and spreading at $120 \mathrm{~kg} \mathrm{~N} \mathrm{ha}^{-1}$ or more. It was likely that changing in canopy shape was due to increasing in canopy width. Consequently, wider plant spacing should be adopted when high $\mathrm{N}$ fertilizer was applied. According to Jiang et al. (2013), root formation is important in determining planting distance. In present study, total root length was $379.9 \mathrm{~cm}, 978.2$ $\mathrm{cm}, 1024.8 \mathrm{~cm}$ and $1198.3 \mathrm{~cm}$ from plants treated with $0,60,120$ and $180 \mathrm{~kg} \mathrm{~N} \mathrm{ha}^{-1}$, respectively. Putriantari and Santosa (2014) have noted that maximum individual root length in $S$. americanum is $66-71 \mathrm{~cm}$, irrespective of $\mathrm{N}$ application.

Increasing canopy width for plant receiving $\mathrm{N}$ application could be explained by increasing number of node, increasing internode length, and increasing branch number. Morphologically, S. nigrum plant produced single primary stem; followed by 1-2 secondary branches, and many tertiary and quarterly branches types dependent on $\mathrm{N}$ level. Primary stem had of 12-13 internodes, irrespective of $\mathrm{N}$ levels. In the present study, secondary branch located on top of primary stem was considered; but the branches grew along primary stem, i.e., $0-2$ on control and $10-11$ on $\mathrm{N}$ treated plants, were excluded from analysis because they are commonly removed by farmers. Plants with supplement $\mathrm{N}$ produced two secondary branches on top of primary stem, and $80 \%$ plants of control produced the same amount. The rest of no $\mathrm{N}$ plants produced single secondary branch.

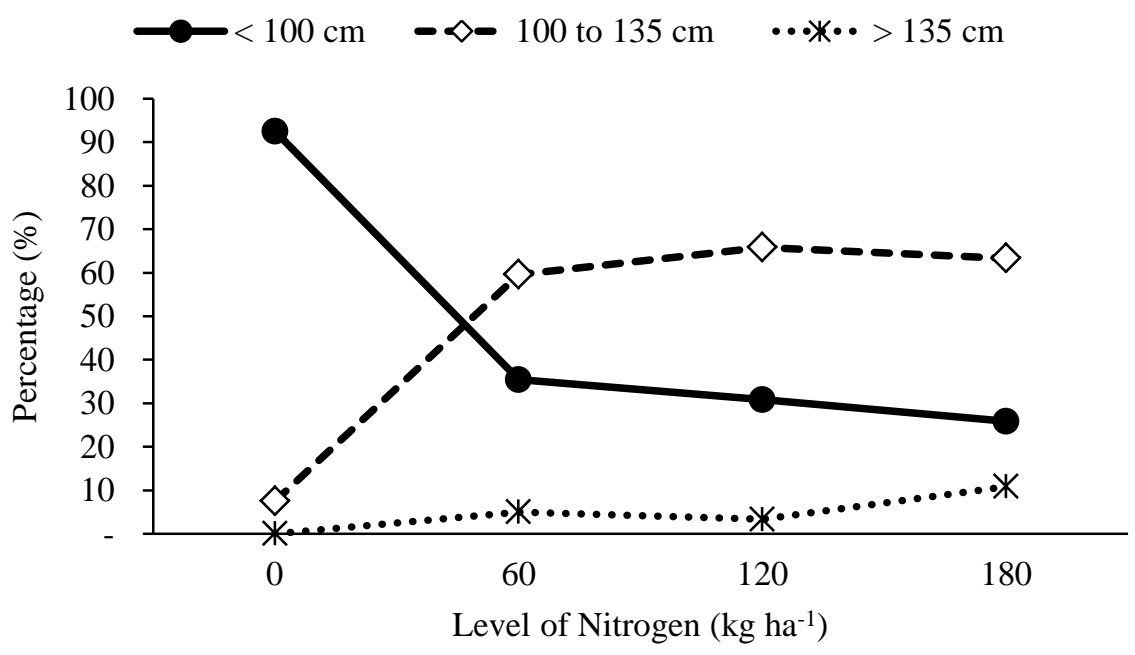

Figure 1. Percentage of S. nigrum plant based on height group from different $\mathrm{N}$ levels. Height was grouped as short $(<100 \mathrm{~mm})$, medium $(100$ to $135 \mathrm{~cm})$ and tall $(>135 \mathrm{~cm})$. 
Table 1. Leaf area index (LAI), ratio and width of canopy, total shoot length and longest branch of S. nigrum cultivated with different N levels

\begin{tabular}{cccccc}
\hline $\begin{array}{c}\text { N level } \\
\left(\mathrm{kg} \mathrm{ha}^{-1}\right)\end{array}$ & LAI $^{\mathrm{x}}$ & $\begin{array}{c}\text { Canopy } \\
\text { Shape }^{\mathrm{x}}\end{array}$ & $\begin{array}{c}\text { Canopy Width } \\
(\mathrm{cm}))^{\mathrm{x}, \mathrm{y}}\end{array}$ & $\begin{array}{c}\text { Total Shoot Length } \\
(\mathrm{cm}){ }^{\mathrm{z}, *}\end{array}$ & $\begin{array}{c}\text { Number of } \\
\text { Internode* }^{*}\end{array}$ \\
\hline 0 & $0.92 \mathrm{~d}$ & $1.00 \mathrm{~d}$ & $93.0 \mathrm{c}$ & $753.3 \mathrm{~d}$ & $268.5 \mathrm{~d}$ \\
60 & $1.76 \mathrm{c}$ & $1.34 \mathrm{c}$ & $147.8 \mathrm{~b}$ & $1314.9 \mathrm{c}$ & $456.1 \mathrm{c}$ \\
120 & $2.91 \mathrm{~b}$ & $1.59 \mathrm{~b}$ & $177.3 \mathrm{ab}$ & $1675.6 \mathrm{~b}$ & $524.1 \mathrm{~b}$ \\
180 & $3.29 \mathrm{a}$ & $1.96 \mathrm{a}$ & $221.5 \mathrm{a}$ & $2182.0 \mathrm{a}$ & $744.6 \mathrm{a}$ \\
\hline V
\end{tabular}

Values in each column followed by different letters are significantly different by DMRT at the 5\% levels; ${ }^{\mathrm{x}}$ at 12 WAP; ${ }^{\mathrm{y}}$ Horizontal distant from the tip of a branch to the tip of opposite branch; ${ }^{\mathrm{z}}$ Lateral branch longer than $20 \mathrm{~mm}$ were counted; * at $16 \mathrm{WAP}$.

Every branches grew out from axillary buds that were formed at nodes. Extension growth of secondary, tertiary and quarterly branches were marked by increasing $\mathrm{N}$ levels. For example, the longest secondary branches in plants treated with $0,60,120$ and $180 \mathrm{~kg} \mathrm{~N}$ $\mathrm{ha}^{-1}$ were $51.3,83.8,92.8$ and $121.3 \mathrm{~cm}$ at 12 WAP, respectively. Most plants treated with $120 \mathrm{~kg} \mathrm{~N} \mathrm{ha}^{-1}$ or lower produced single branch on each node; and $180 \mathrm{~kg} \mathrm{~N}^{-1}$ plants had two or more branches on each node. As a result, total shoot length control plants was about one third of those in plants received 180 $\mathrm{kg} \mathrm{N} \mathrm{ha}^{-1}$ (Table 1).

Table 1 indicated that number of internode increased by $69.9 \%$ and $177.3 \%$ of plants at $\mathrm{N}$ level of 60 and $180 \mathrm{~kg} \mathrm{~N} \mathrm{ha}{ }^{-1}$, respectively relative to control. Maximum internode length, irrespective on the type of branch, was $14-18 \mathrm{~cm}$ in plants received $60 \mathrm{~kg}$ $\mathrm{N} \mathrm{ha}^{-1}$ or higher, and $10-12 \mathrm{~cm}$ in control plants at 12 WAP. Increasing number of branch and internode length on $S$. nigrum by increasing level of nutrient have been studied (Ondieki et al., 2011; Nyagari et al., 2016).

\section{Dry Matter Production and Its Partitioning}

Dry mass production was affected by $\mathrm{N}$ level (Table 2), in line with finding by Opiyo (2004). Fruit load as represented by the ratio dry mass of fruit to leaf was the highest in plants of $0 \mathrm{~kg} \mathrm{~N}^{-1}$ at $6 \mathrm{WAP}$, and $60 \mathrm{~kg} \mathrm{~N}$ $\mathrm{ha}^{-1}$ at 12 WAP. A decrease in this ratio in control plants at $12 \mathrm{WAP}$ suggests that fruit production in $S$. nigrum was not solely dependent on $\mathrm{N}$ availability. In $180 \mathrm{~kg} \mathrm{~N} \mathrm{ha}^{-1}$ application, on the other hand, plants allocated more assimilate to develop leaves and stem, irrespective plant age (Table 2).

The ratio of root dry mass to total dry mass was almost the same among treatments at 6 WAP, but it decreased in plants received 180 $\mathrm{kg} \mathrm{N} \mathrm{ha}{ }^{-1}$ at 12 WAP. It appears that plant tended to translocate more dry mass into roots as compared to above-ground parts when $\mathrm{N}$ availability was insufficient; inline with result of Bvenura and Afolayan (2014).

\section{Inflorescence and Fruit Production}

An inflorescence emerged from the middle of internode; thus number of inflorescences was determined by number of node. Two distinct peaks of flowering and fruit set were observed on weekly basis (Figure 2). The second peaks were higher on the number of flowering than the first peaks in all treatments. Regardless of $\mathrm{N}$ level, the number of flowers decreased in $8 \mathrm{WAP}$ and $9 \mathrm{WAP}$ at which time the amount of rainfall was decreased, i.e., $116.7 \mathrm{~mm}$ and $8.2 \mathrm{~mm}$ per week, respectively (Figure 2A). On the other hand, the number of fruits decreased sharply in 11 WAP or two weeks after the driest week (Figure 2B). Thus, the effect of rainfall on $S$. nigrum flowering was likely within a week while its effect on fruiting was apparent two weeks later. Although supplemental irrigation was regularly applied, the amount of water was unlikely to be adequate due to high transpirasion rates. 
Table 2. Dry mass (DM) plant parts and its ratio of S. nigrum cultivated under different $\mathrm{N}$ levels at 6 and 12 WAP

\begin{tabular}{|c|c|c|c|c|}
\hline \multirow{2}{*}{ Plant Part } & \multicolumn{4}{|c|}{ Level of Nitrogen } \\
\hline & $0 \mathrm{~kg} \mathrm{~N}$ & $60 \mathrm{~kg} \mathrm{~N}$ & $120 \mathrm{~kg} \mathrm{~N}$ & $180 \mathrm{~kg} \mathrm{~N}$ \\
\hline & \multicolumn{4}{|c|}{ 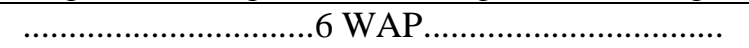 } \\
\hline Leaves DM (g) & $5.10 \mathrm{c}$ & $9.91 \mathrm{~b}$ & $12.20 \mathrm{~b}$ & $17.76 \mathrm{a}$ \\
\hline Roots DM (g) & $2.71 \mathrm{c}$ & $5.82 \mathrm{~b}$ & $7.58 \mathrm{ab}$ & $8.07 \mathrm{a}$ \\
\hline Shoots and branches DM $(g)^{y}$ & $8.15 \mathrm{c}$ & $19.53 \mathrm{~b}$ & $22.36 \mathrm{~b}$ & $30.21 \mathrm{a}$ \\
\hline Flower DM $(\mathrm{g})$ & $0.33 \mathrm{~d}$ & $0.52 \mathrm{c}$ & $0.77 \mathrm{~b}$ & $0.91 \mathrm{a}$ \\
\hline Fruits (all size) DM (g) & $2.91 \mathrm{~b}$ & $3.85 \mathrm{a}$ & $4.37 \mathrm{a}$ & $5.21 \mathrm{a}$ \\
\hline Ratio Fruit DM to leaf DM $\left(\mathrm{gg}^{-1}\right)$ & $0.57 \mathrm{a}$ & $0.39 \mathrm{~b}$ & $0.36 \mathrm{~b}$ & $0.29 \mathrm{c}$ \\
\hline Ratio Root DM to total DM $\left(\mathrm{gg}^{-1}\right)$ & $0.16 \mathrm{~b}$ & $0.17 \mathrm{~b}$ & $0.19 \mathrm{~b}$ & $0.15 \mathrm{~b}$ \\
\hline Ratio Fruit DM to total DM $\left(\mathrm{gg}^{-1}\right)$ & $0.15 \mathrm{a}$ & $0.10 \mathrm{~b}$ & $0.09 \mathrm{~b}$ & $0.08 \mathrm{~b}$ \\
\hline Leaves DM & $1.43 \mathrm{c}$ & \multicolumn{3}{|c|}{.............12 WAP............ } \\
\hline Roots DM (g) & $4.23 \mathrm{~b}$ & $10.35 \mathrm{a}$ & $11.87 \mathrm{a}$ & $13.28 \mathrm{a}$ \\
\hline Shoots and branches DM $(g)^{\mathrm{y}}$ & $18.84 \mathrm{c}$ & $41.07 \mathrm{~b}$ & $55.47 \mathrm{ab}$ & $71.16 \mathrm{a}$ \\
\hline Flower DM $(\mathrm{g})$ & $0.30 \mathrm{c}$ & $0.86 \mathrm{~b}$ & $2.02 \mathrm{a}$ & $2.35 \mathrm{a}$ \\
\hline Fruits (all size) DM (g) & $0.20 \mathrm{~b}$ & $4.43 \mathrm{a}$ & $3.81 \mathrm{a}$ & $5.28 \mathrm{a}$ \\
\hline Ratio Fruit DM to leaf DM $\left(\mathrm{gg}^{-1}\right)$ & $0.14 \mathrm{c}$ & $0.61 \mathrm{a}$ & $0.46 \mathrm{~b}$ & $0.36 \mathrm{~b}$ \\
\hline Ratio Root DM to total DM $\left(\mathrm{gg}^{-1}\right)$ & $0.20 \mathrm{a}$ & $0.19 \mathrm{a}$ & $0.17 \mathrm{ab}$ & $0.14 \mathrm{~b}$ \\
\hline Ratio Fruit DM to total DM $\left(\mathrm{gg}^{-1}\right)$ & $0.01 \mathrm{~b}$ & $0.07 \mathrm{a}$ & $0.05 \mathrm{a}$ & $0.05 \mathrm{a}$ \\
\hline
\end{tabular}

Values in each row at the same plant part followed by different letters are statistically different by DMRT at the 5\% levels. ${ }^{\mathrm{y}}$ Petioles, pedicel and calyces were incorporated to shoot and branches dry mass calculation.

During a period with much precipitation, i.e., 4-6 WAP (Figure 2A), 36.2-90.8 inflorescences reached anthesis in a plant on average. The number of inflorescences reaching anthesis gradually decreased, and attained minimum values 9 WAP. Thereafter, it increased gradually to return the values of 4 WAP. The periods between February 11 and 21, and between March 9 and 16, 2014 were the driest periods with no adequate consecutive rainfall $(0-2.5 \mathrm{~mm}$ per day). Some plants received 120 and $180 \mathrm{~kg} \mathrm{~N}^{-1}{ }^{-1}$ wilted at midday, but recovered in the afternoon by irrigation. Due to more frequent wilting at 14 WAP and later, the number of flowers decreased to nearly zero in plants treated with 120 and $180 \mathrm{~kg} \mathrm{~N}^{-1}$ (Figure 2). N application decreased the ratio of root dry mass to total dry mass (Table 2), leading to the imbalance between transpiration and water absorption. This suggests that an adequate irrigation is needed along with $\mathrm{N}$ application for achieving high productivity.

The number of fruits set per plant per week significantly increased with the increase in plant age and $\mathrm{N}$ levels (Figure 2B). The number of flowers on an inflorescence ranged from 4-13, irrespective of $\mathrm{N}$ levels. However, the percentage of inflorescences with 4 flowers or more increased by $\mathrm{N}$ application. Since flower drop was rare, it was likely that the number of fruits on each inflorescence was determined by the number of flowers. In general, $\mathrm{N}$ application at rate $60-180 \mathrm{~kg} \mathrm{~N}^{-1}$ increased the number of fruits by $169-235 \%$ at 6 WAP, and $1824-2194 \%$ at 12 WAP as compared with control. Since plants produced flowers and fruits continuously, plant carried flowers and fruits with different age or size at a time. Therefore, farmers harvested the fruits once or twice a week. 


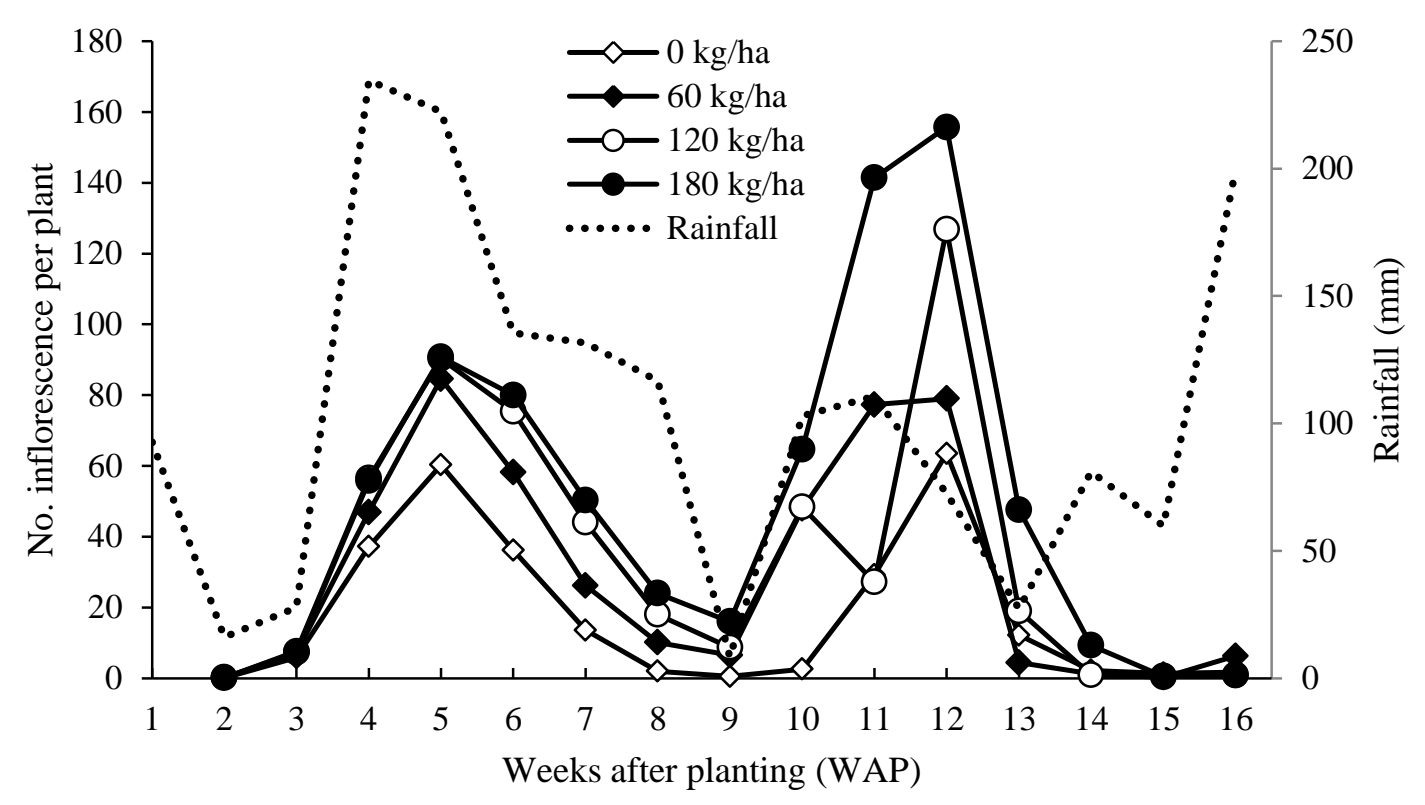

(A)

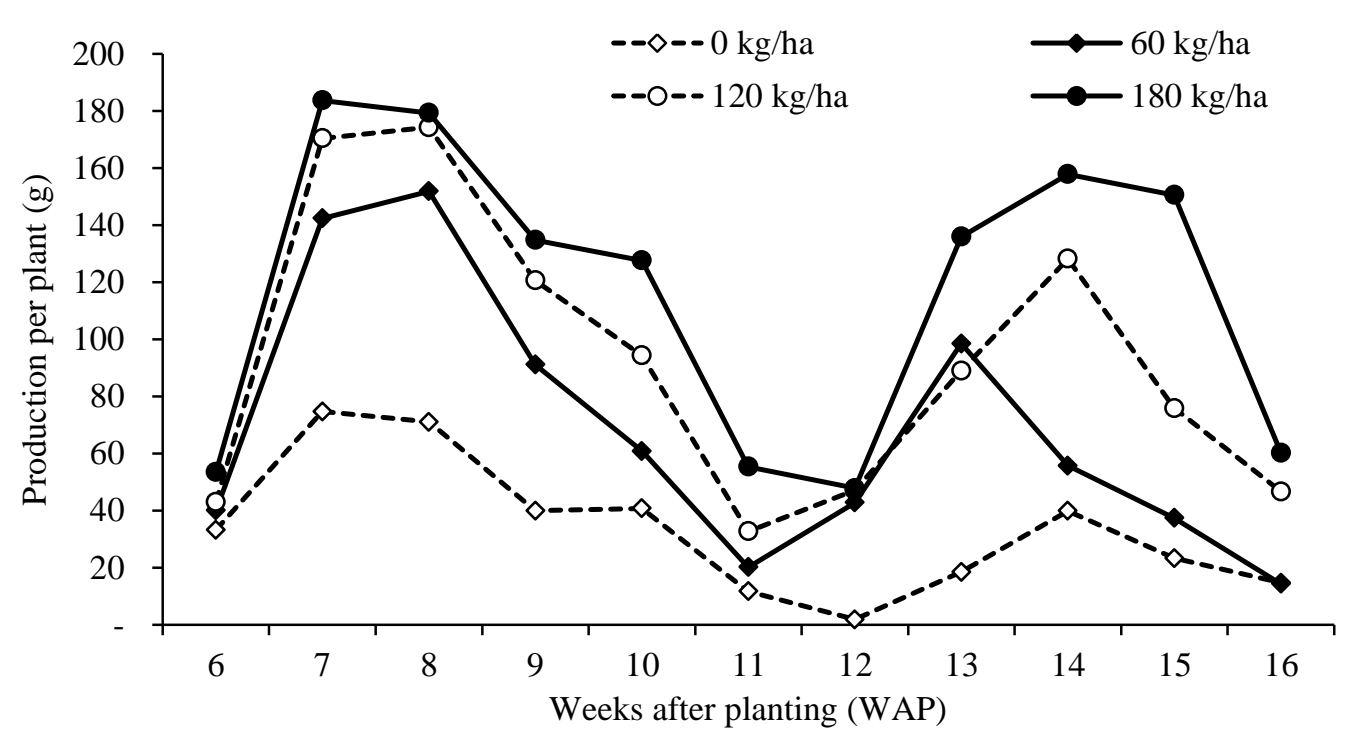

(B)

Figure 2. Weekly number of inflorescence reaching anthesis (A) and fruit production (B) of $S$. nigrum as affected by different $\mathrm{N}$ levels.

\section{Fruit Quality}

Small-, medium- and large-sized fruits mixed in the harvest because the fruits were harvested on the basis of an inflorescence. Consumers like medium and large-sized fruits at dark green stage. Fruits at black stage was allowable less than $10 \%$, because the black fruit was considered as over-matured by consumers. The percentage of black fruits at harvest of 10 WAP were $49.9 \%$ in plants treated with $0 \mathrm{~N} \mathrm{~kg} \mathrm{ha}^{-1}$, while $30.3-36.5 \%$ in other $\mathrm{N}$ levels. Nevertheless, number of overmatured fruits was unlikely affected by $\mathrm{N}$ levels in other harvesting times. Thus, harvesting time and $\mathrm{N}$ level are important on the fruit quality. 
Table 3. The number and fresh mass of fruits according to fruit size of $S$. nigrum plants cultivated under different $\mathrm{N}$ levels harvested at 6 and 12 weeks after planting (WAP)

\begin{tabular}{|c|c|c|c|c|c|c|}
\hline \multirow{2}{*}{$\begin{array}{l}\text { N Level } \\
\left(\mathrm{kg} \mathrm{ha}^{-1}\right)\end{array}$} & \multicolumn{2}{|c|}{ Small $(<3 \mathrm{~mm})$} & \multicolumn{2}{|c|}{ Medium (3-7 mm) } & \multicolumn{2}{|c|}{ Large $(>7 \mathrm{~mm})$} \\
\hline & 6 WAP & 12 WAP & $6 \mathrm{WAP}$ & 12 WAP & $6 \mathrm{WAP}$ & 12 WAP \\
\hline & \multicolumn{6}{|c|}{ 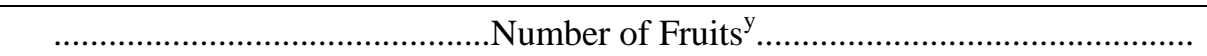 } \\
\hline 0 & $54.3 \mathrm{~b}$ & $9.8 \mathrm{~b}$ & $39.3 \mathrm{a}$ & $5.0 \mathrm{~b}$ & $51.8 \mathrm{a}$ & $2.8 \mathrm{~b}$ \\
\hline 60 & $142.5 \mathrm{a}$ & $197.5 \mathrm{a}$ & $47.3 \mathrm{a}$ & $69.0 \mathrm{a}$ & $55.3 \mathrm{a}$ & $56.8 \mathrm{a}$ \\
\hline 120 & $153.0 \mathrm{a}$ & $177.0 \mathrm{a}$ & $70.8 \mathrm{a}$ & $96.8 \mathrm{a}$ & $43.0 \mathrm{a}$ & $45.5 \mathrm{a}$ \\
\hline \multirow{2}{*}{180} & $185.8 \mathrm{a}$ & $212.5 \mathrm{a}$ & $89.3 \mathrm{a}$ & $109.3 \mathrm{a}$ & $67.0 \mathrm{a}$ & $62.3 \mathrm{a}$ \\
\hline & \multicolumn{6}{|c|}{ 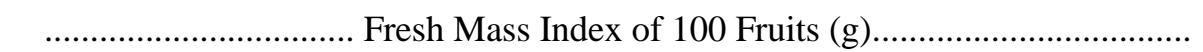 } \\
\hline 0 & $2.5 \mathrm{a}$ & $3.5 \mathrm{a}$ & $9.9 \mathrm{~b}$ & $16.1 \mathrm{a}$ & $56.2 \mathrm{a}$ & $40.0 \mathrm{~b}$ \\
\hline 60 & $4.4 \mathrm{a}$ & $3.6 \mathrm{a}$ & $20.9 \mathrm{ab}$ & $15.7 \mathrm{a}$ & $58.7 \mathrm{a}$ & $50.5 \mathrm{ab}$ \\
\hline 120 & $4.3 \mathrm{a}$ & $3.0 \mathrm{a}$ & $27.3 \mathrm{a}$ & $14.0 \mathrm{a}$ & $68.8 \mathrm{a}$ & $63.1 \mathrm{a}$ \\
\hline 180 & $3.8 \mathrm{a}$ & $3.9 \mathrm{a}$ & $17.7 \mathrm{ab}$ & $16.0 \mathrm{a}$ & $60.2 \mathrm{a}$ & $54.4 \mathrm{ab}$ \\
\hline
\end{tabular}

Value in each column followed by different letters are significantly different by DMRT at the 5\% levels; ${ }^{y}$ Fruits were categorized based on diameter.

Distribution pattern of fruit size and weight in each harvesting time were affected by $\mathrm{N}$ application (Table 3). In harvest of control plants without $\mathrm{N}$ application, the percentages of small-, medium- and largesized fruits at 6 WAP were almost the same, i.e., 37,27 and $36 \%$ of total fruit, respectively. $\mathrm{N}$ application increased the percentage of small fruits; the percentage of small fruits was $54-55 \%$ of total fruits harvested at same date from $180 \mathrm{~kg} \mathrm{~N} \mathrm{ha}^{-1}$. In this experiment, the fruits became mature within less than a week after they attained full size. It implied that at high $\mathrm{N}$ fertilizer, more frequent harvesting should be considered.

$\mathrm{N}$ application at rate $120 \mathrm{~kg} \mathrm{ha}^{-1}$ increased fresh masses index of the 100 fruits of medium-sized at $6 \mathrm{WAP}$, and the index of large-sized fruits at 12 WAP (Table 3). Table 3 showed increasing number of fruit in $\mathrm{N}$ treated plant at 12 WAP. It indicated that the yield-increasing effect of $\mathrm{N}$ application in Figure $2 \mathrm{~B}$ was due to fruit number-increasing effect.

Fruit cracking was observed in irrespective $\mathrm{N}$ treatment (Figure 3); it ranged from $0-5$ fruits per plant for each harvesting week. Incidence of fruit cracking was initially detected as brown ring or spot around pedicels (Figure 3A). The phenomenon was unlikely due to $\mathrm{Ca}$ defficiency because $\mathrm{Ca}$ level in the soil was adequate. Rapid expansion of fruit after rainfall was considered to expand the opening at the ring or spots, leading to cracking (Figure 3B). Thus, the fruit cracking could relate to high water availability in the soil after severe drought; although Capel et al. (2017) stated that fruit cracking in tomato due to genetic factor.
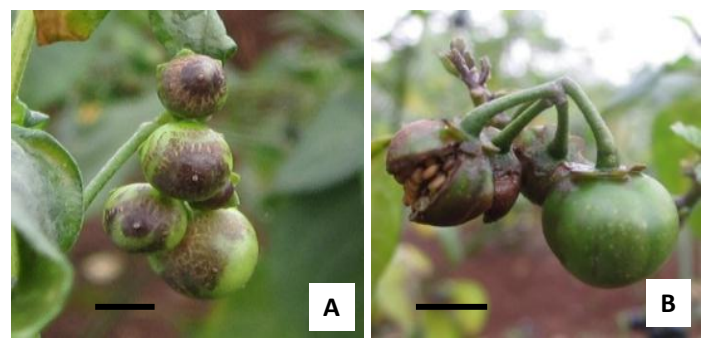

Figure 3. Brown spot (A) and fruits cracking (B) in fruits of S. nigrum. Bar $\pm 5 \mathrm{~mm}$.

\section{CONCLUSION}

Application of nitrogen significantly determined canopy architecture, dry matter and fruit production, and fruit quality of $S$. nigrum. At least the amount of nitrogen fertilizer at rate $60 \mathrm{~kg} \mathrm{~N}^{-1} \mathrm{a}^{-1}$ should be applied to increase fruit yield of $S$. nigrum and to maintain efficiency on labor force for harvesting.

\section{ACKNOWLEDGEMENT}

The authors wish to thank Prof Sobir from Center for Tropical Horticulture Studies IPB for correcting scientific name of material used as Solanum nigrum L. 


\section{REFERENCES}

Bvenura, C., A.J. Afolayan. 2014. Growth and physiological response of Solanum nigrum L. to organic and/or inorganic fertilisers. J. Appl. Bot. Food Quality. 87: 168-174. doi:10.5073/JABFQ.2014. 087. 024.

Capel, C., F.J. Yuste-Lisbona, G. LópezCasado, T. Angosto, J. Cuartero, R. Lozano. 2017. Multi-environment QTL mapping reveals genetic architecture of fruit cracking in a tomato RIL Solanum lycopersicum $\times$ S.pimpinellifolium popul ation. Theor. Appl. Genet. 130(1): 213222. doi: 10.1007/s00122-016-2809-9.

Degri, M.M. 2014. The effect of spacing of egg plant (Solanum melongena L.) (Solanaceae) on shoot and fruit borer (Leucinodes orbonalis Guen.) Lepidoptera: Pyralidae infestation in the dry savanna zone of Nigeria. Agric. Biol. J. N. Am. 5(1): 10-14. doi:10.5251/ abjna.2014.5.1.10.14.

Edmonds, J.M., J.A. Chweya. 1997. Black nightshades. Solanum nigrum L. and related species. Promoting the conservation and use of underutilized and neglected crops. 15. Institute of Plant Genetics and Crop Plant Research, Gatersleben/International IPGRI, Rome, Italy. p113.

Etissa, E., N. Dechassa, T. Alamirew, Y. Alemayehu, L. Desalegn. 2013. Growth and yield components of tomato as influenced by nitrogen and phosphorus fertilizer applications in different growing season. Ethiop. J. Agric. Sci. 23: $57-77$

Gogoi, P., M. Islam. 2012. Phytochemical screening of Solanum nigrum L and S. myriacanthus Dunal from districts of Upper Assam, India. IOSR J. Pharmacy. 14: $455-459$

Gokavi, N., M. Ravikumar, H.J. Shivakumar. 2014. Effect of spacing and NPK on growth, yield and nutrient uptake by makoi (Solanum nigrum L.) under hill zone of Karnataka. Internat. J. Dev. Res. 4(7): 1424-1427.

Jain, R., A. Sharma, S. Gupta, I.P. Sarethy, R. Gabrani. 2011. Solanum nigrum: Current perspectives on therapeutic properties. Alternative Med. Rev. 16(1): 78-85.

Jiang, W., K. Wang, Q. Wu, S. Dong, P. Liu, J. Zhang. 2013. Effects of narrow plant spacing on root distribution and physiological nitrogen use efficiency in summer maize. Crop J. 1(1): 77-83. doi: 10.1016/j.cj.2013.07.011.

Karmakar, U.K., U.K. Tarafder, S.K. Sadhu, N.N. Biswas, M.C. Shill. 2010. Biological investigation of dried fruit of Solanum nigrum Linn. Stamford J. Pharmaceutical Sci. 3(1): 38-45.

Mohy-ud-din, A., Z. Kahn, M. Ahmed, M.A. Kashmiri. 2010. Chemotaxonomic value of alkaloids in Solanum nigrum complex. Pak. J. Bot. 42: 653-660.

Nyagari, E., C.M. Onyango, R.N. Onwong'a. 2016. Effects of intercropping arrangements and fertilizer application on growth and yield of African nightshade (Solanum nigrum L.) in Kisii County, Kenya. IJAER. 2(5): 10691083.

Ondieki, M.J., J.N. Aguyoh, A.M. Opiyo. 2011. Fortified compost manure improves yield and growth of African nightshades. Internat. J. Sci. Nat. 2(2): 231-237.

Opiyo, A.M. 2004. Effect of nitrogen application on leaf yield and nutritive quality of black nighshade Solanum nigrum L. Outlook on Agric. 33(3): 209214.

Putriantari, M., E. Santosa. 2014. Growth and alkaloids levels of Leunca (Solanum americanum Miller) of different nitrogen application. J. Hort. Indonesia. 5(3): 175-182.

Ravi, C.S., B.S. Sreeramu, A.P.M. Gowda, G.R. Smitha. 2013. Evaluation of makoi 
(Solanum nigrum L.) germplasm for growth, yield and quality. J. Appl. Hort. 15(2): 133-137.

Ravi, V., T.S.M. Saleem, S.S. Patel, J. Raamamurthy, K. Gauthaman. 2009. Anti-inflammatorry effect of methanolic extract of Solanum nigrum Linn Berries. IJARNP. 2(2): 33-36.

Santosa, E., U. Pratiwi, Sobir, Y. Mine, N. Sugiyama. 2015. Agronomy, utilization and economics of indigenous vegetables in West Java, Indonesia. J. Hort. Indonesia. 6(3): 125-134.
Sarlikioti, V., P.H.B. de Visser, G.H. BuckSorlin, L.F.M. Marcelis. 2011. How plant architecture affects light absorption and photosynthesis in tomato: towards an ideotype for plant architecture using a functional-structural plant model. Ann. Bot. 108: 1065-1073. doi:10.1093/aob/ mcr221.

Sudhanshu, N. Rao, S. Mittal, E. Menghani. 2012. Antioxidant activity of Solanum surratense and Solanum nigrum methanolic extract: an in vitro evaluation. JAPR. 3(1): 9-12. 